CASSOWARY volume 5 (1) Januari 2022: 58 - 68

ISSN : 2614-8900

E-ISSN : 2622-6545

Program Pascasarjana Universitas Papua, https://pasca.unipa.ac.id/

\title{
Penerapan delapan fungsi keluarga dan dampak terhadap kesejahteraan keluarga di Kabupaten Sorong
}

\author{
Benyamin Lado1, Hugo Warami ${ }^{1)^{*}}$, Ihwan Tjolli1) \\ ${ }^{1)}$ Program Studi Ilmu Lingkungan, Program Pascasarjana, Universitas Papua, Jalan \\ Gunung Salju, Amban, Manokwari, Papua Barat, 98314, Indonesia \\ *Email: h.warami@unipa.ac.id
}

Disubmit: 19 Maret 2021, direvisi: 10 Januari 2022, diterima: 26 Januari 2022

Doi: https://doi.org/10.30862/casssowary.cs.v5.i1.87

\begin{abstract}
ABSTRACK: This study aims to analyze the level of application of the eight family functions, the factors that influence and the effect of the level of application of the eight family functions on family welfare. The number of samples is 116 samples and the research methods are descriptive and quantitative. Data processing and analysis using multiple linear regression and simple linear regression. The results showed (1) the application of the eight family functions was in the medium category; (2) the results of multiple linear regression analysis, show that the variables of formal education, age, frequency of socialization together affect the level of implementation of the eight family functions; (3) the results of simple linear regression analysis show that the variable level of application of eight family functions has a significant effect on the level of family welfare.
\end{abstract}

Keywords: eight family functions; well-being

\section{PENDAHULUAN}

Kesejahteraan bagi semua orang merupakan isu penting dunia sehingga menjadi bagian dari 8 tujuan pembangunan millennium (millennium development goals atau MDGs) dan isu tersebut dilanjutkan sampai dengan tahun 2030 melalui pembangunan berkelanjutan 2015-2030 (the 2030 Agenda for Sustainable Development atau SDGs) dengan agenda prioristas yang meliputi dimensi sosial, ekonomi dan lingkungan hidup. Tujuan pembangunan berkelanjutan memiliki 17 tujuan dan 169 target, dan yang berkaitan dengan judul jurnal ini adalah: (1) Tanpa Kemiskinan (Annur, 2013); (2) Tanpa
Kelaparan; (3) Kehidupan Sehat dan Sejahtera.

Indonesia sebagi salah satu dari 193 negara anggota Perserikatan Bangsa-Bangsa yang berperan aktif dalam penentuan sasaran Tujuan Pembangunan Berkelanjutan, sangat berkomitmen secara umum tujuan dan target SDGs telah diselaraskan dengan target RPJMN 2015-2019 yakni tujuan kemiskinan, kesehatan, pendidikan, ketimpangan, air dan sanitasi, serta akses energi (dari MDGs ke SDGs: 3). Arah pembangunan bangsa selama 5 tahun makin dipertegas dengan 9 agenda prioritas pembangunan yang dikenal dengan Nawacita, dan khusus yang berkaitan dengan Pembangunan 
Keluarga, Kependudukan dan Keluarga Berencana (Bangga Kencana), meliputi agenda ke 3 yakni membangunan dari pinggiran; agenda ke 5 meningkatkan kualitas Sumber Daya Manusia Indonesia dan agenda ke 8 melakukan revolusi karakter (BAPENNAS, 2017).

Pembangunan idealnya dimulai dari keluarga oleh karena keluarga merupakan unit terkecil dalam masyarakat dan keluarga merupakan lembaga pertama dan utama untuk menanamkan nilai - nilai luhur kehidupan agar terbentuknya karakter sejak dini (BKKBN, 2019a, 2019b). Apabila pembangunan berbasis keluarga berhasil tentu memberikan dampak kesejahteraan bagi bangsa dan negara (Elmanora, 2015). Pasal 47 - 48 Undang - undang RI Nomor 52 Tahun 2009 menegaskan bahwa Pembangunan Keluarga bertujuan untuk mendukung keluarga dalam melaksanakan fungsi keluarga secara optimal (Republik Indonesia, 2009).

Setiap keluarga diharapkan mampu menerapkan 8 fungsi keluarga dengan baik sehingga seluruh anggota keluarga bertumbuh dan berkembang menjadi sumber daya manusia yang berkualitas, bukan saja dari aspek kognitif tetapi juga dari aspek karakater. Kualitas hidup anggota keluarga dapat dimulai dengan menerapkan setiap indikator dari fungsi keluarga yakni fungsi Agama; Fungsi Sosial Budaya; Fungsi Cinta Kasih; Fungsi Perlindungan; Fungsi Reproduksi; Fungsi Sosialisasi dan Pendidikan; Fungsi Ekonomi dan Fungsi Lingkungan (Wijayanti \& Berdame, 2019). Penerapan delapan fungsi untuk mewujudkan kesejahteraan keluarga yakni dapat menjalani kehidupan yang baik dimana seseorang merasa puas baik terhadap kegiatan yang dilakukan secara rutinitas dalam memenuhi kebutuhan dasar hidup maupun hubungan dengan sesamanya dan dengan lingkungan hidupnya.

Tujuan penelitian yakni menganalisis faktor pengaruh penerapan 8 fungsi keluarga serta menganalisis dampak terhadap kesejahteraan keluarga.

\section{METODE PENELITIAN}

Penelitian dilaksanakan di Kabupaten Sorong yakni meliputi kampung Fafi, kampung Maibo, kampung Katinim dan kampung Walal. Alat yang digunakan dalam penelitian adalah kamera, alat tulis menulis, perekam suara, kuesioner untuk melakukan wawancara langsung serta checklist. Jenis penelitian ini merupakan jenis penelitian deskriptif dan kuantitatif yang akan menggambarkan dan menganalisis keterkaitan antar X dan Y; Y dan Z1 (Sugiyono, 2011). Populasi dalam penelitian ini adalah keluarga keluarga yang telah mendapatkan sosialisasi program bangga kencana, dengan Teknik sebagai berikut:

1. Penetuan Populasi yang akan menjadi subjek penelitian menggunakan metode Purposive sampling, oleh karena informasi yang akan diambil berasal dari sumber yang sengaja dipilih berdasarkan kriteria yang ditetapkan".

2. Kriteria yang ditetapkan adalah "Keluarga yang masih memiliki pasangan, dan memiliki anak yang tinggal Bersama". Setelah melakukan identifikasi, ditemukan 577 populasi yang sesuai dengan kriteria yang dinginkan untuk diteliti.

3. Ukuran sampel ditentukan melalui perhitungan dengan menggunakan rumus Slovin. 
Rumus Slovin:

Keterangan:

$$
n=\frac{N}{1+N \cdot(e)^{2}}=\frac{577}{1+577 \cdot(0.10) 2)}=\frac{577}{4,96}=116,33 \approx 116
$$

$\mathrm{n}=$ jumlah sampele, $\mathrm{N}=$ jumlah total populasi, $\mathrm{e}=$ Batas Toleransi Error, $\mathrm{e}=$ Selang kepercayaan $90 \%(\alpha=0,1)$

4. Penentuan jumlah sampel untuk masing-masing kampung dilakukan secara proporsional dengan rumus (Nasir, 1988), oleh karena rumus yang dikemukakan oleh Nasir sederhana dan tepat untuk menghitung sampel secara proporsional. Rumus proportional sampling :

$$
\mathrm{ni}=\frac{\mathbf{N i}}{\mathbf{N}} \times \mathbf{n}
$$

Keterangan :

ni : Besarnya sampel pada kampung Fafi

$\mathrm{Ni}$ : Besarnya populasi pada kampung Fafi

$\mathrm{N}$ : $\quad$ Besarnya populasi keseluruhan

$\mathrm{n}$ : Besarnya ukuran sampel

Untuk mengetahui pengaruh tingkat pendidikan, umur, dan frekuensi sosialisasi terhadap tingkat penerapan delapan fungsi keluarga, digunakan analisis Regresi Linier Berganda (linier multiple regression) dengan menggunakan program SPSS versi 21 .

Keterangan :

$$
\mathbf{Y}=\mathbf{b}_{1} \mathbf{X}_{1}+\mathbf{b}_{2} \mathbf{X}_{2}+\mathbf{b}_{3} \mathbf{X}_{3}
$$

$\mathrm{Y} \quad=$ Tingkat Penerapan

$\mathrm{b}_{1-3}=$ Koefisien regresi

$\mathrm{X}_{1} \quad=$ Pendidikan formal

$\mathrm{X}_{2}=$ Umur

$\mathrm{X}_{3}=$ Frekuensi Sosialisasi

Untuk menguji adanya pengaruh pendidikan formal, umur, frekuensi sosialisasi terhadap tingkat penerapan delapan fungsi keluarga digunakan uji $F_{\text {hitung }}$ sebagai berikut (Gujarati,1997) :

$$
F_{\text {hitunh }}=\frac{R^{2} /(k-1)}{\left(1-R^{2}\right) /(n-k)}
$$

Keterangan :

$R^{2}=$ koefisien determinasi berganda

$k=$ banyaknya variabel bebas

$n$ = banyaknya sampel

Perumusan hipotesis :

$\mathrm{H}_{0}$ : Variabel $\mathrm{X}_{1}, \mathrm{X}_{2}, \mathrm{X}_{3}, \quad$ secara simultan tidak berpengaruh terhadap variabel tidak bebas

$\mathrm{H}_{1}$ : Variabel $\mathrm{X}_{1}, \mathrm{X}_{2}, \mathrm{X}_{3}$ secara simultan berpengaruh terhadap variabel tidak bebas

Kriteria pengujian :

1. Jika probabilitas $F_{\text {hitung }}<0,05$ dengan derajat kebebasan $\mathrm{df}=(\mathrm{n}-\mathrm{k}-1)$, maka $\mathrm{H}_{0}$ ditolak dan $\mathrm{H}_{1}$ diterima, artinya ada pengaruh yang signifikan antara pendidikan formal, umur, frekuensi sosialisasi terhadap tingkat penerapan delapan fungsi keluarga.

2. Jika probabilitas $F_{\text {hitung }}>0,05$ dengan derajat kebebasan $\mathrm{df}=(\mathrm{n}-\mathrm{k}-1)$, maka $\mathrm{H}_{0}$ diterima dan $\mathrm{H}_{1}$ ditolak, artinya tidak ada pengaruh yang signifikan antara pendidikan formal, umur, frekuensi sosialisasi terhadap tingkat penerapan delapan fumgsi keluarga.

Pengujian secara parsial antara pendidikan formal, umur, frekuensi sosialisasi terhadap tingkat penerapan delapan fungsi keluarga digunakan uji $t_{\text {hitung, }}$, sebagai berikut: 
Keterangan :

$$
t_{\text {hitung }}=\frac{\beta_{i}}{s \beta_{i}}
$$

$\beta_{i} \quad=$ Koefesien regresi

$S \beta_{i}=$ Standar error

Perumusan hipotesis :

$\mathrm{H}_{0}: \beta_{i}=0$, artinya secara parsial pendidikan formal, umur, frekuensi sosialisasi tidak mempunyai pengaruh yang signifikan terhadap tingkat penerapan delapan fungsi keluarga

$\mathrm{H}_{1}: \beta_{i} \neq 0$, artinya secara parsial pendidikan formal, umur, frekuensi sosialisasi tidak mempunyai pengaruh yang signifikan terhadap tingkat penerapan delapan fungsi keluarga.

Kriteria pengujian :

1. Jika probabilitas $t_{\text {hitung }}<\alpha / 1(0,05)$ maka, $\mathrm{H}_{0}$ ditolak dan $\mathrm{H}_{1}$ diterima, artinya ada pengaruh yang signifikan antara pendidikan formal, umur, frekuensi sosialisasi terhadap tingkat penerapan delapan fumgsi keluarga.

2. Jika probabilitas $t_{\text {hitung }}>\alpha / 1(0,05)$ maka, $\mathrm{H}_{0}$ diterima dan $\mathrm{H}_{1}$ ditolak, artinya tidak ada pengaruh yang signifikan antara pendidikan formal, umur, frekuensi sosialisasi terhadap tingkat penerapan delapan fumgsi keluarga.

Untuk mengetahui pengaruh tingkat penerapan delapan fungsi keluarga (Y) terhadap Kesejahteraan Keluarga (Z1), digunakan analisis regresi sederhana, dengan model sebagai berikut :

$$
Z_{i}=a+\beta Y+e
$$

Demikian juga untuk mengetahui pengaruh tingkat penerapan delapan fungsi keluarga (Y) terhadap Lingkungan Sehat (Z2), digunakan analisis regresi sederhana, dengan model sebagai berikut:

$$
Z_{2}=a+\beta Y+e
$$

\section{Method of Succesive Interval (MSI)}

Berhubung data-data merupakan data ordinal, sehingga harus diubah menjadi data interval melalui Method of Succesive Interval (MSI). Setelah data terkumpul, beberapa data skala ordinal terlebih dahulu dilakukan perubahan data ke dalam skala interval. Metode yang digunakan dalam proses transformasi data dari skala ordinal ke skala interval menggunakan Method of Successive Interval.

Tahapan-tahapan Method of Succesive Interval (MSI) adalah sebagai berikut:

1. Menentukan frekuensi setiap respon (fi)

2. Menentukan proporsi setiap respon dengan membagi frekuensi dengan jumlah sampel, dengan rumus:

$$
\mathrm{pi}=\frac{f i}{n}
$$

Dimana:

pi $=$ proporsi

$\mathrm{fi}=$ frekuensi

$\mathrm{n}=$ jumlah responden

3. Menjumlahkan proporsi secara berurutan untuk setiap respon sehingga diperoleh proporsi kumulatif, dengan rumus : Pki $=$ pi $1+\mathrm{p}$

4. Menentukan nilai $\mathrm{Z}$ untuk masingmasing proporsi kumulatif yang dianggap menyebar mengikuti sebaran normal baku. 
5). Menghitung Nilai Skala (NS) untuk masing-masing respon dengan rumus

$$
N S=\frac{\text { Density at Lower limit }- \text { Density at Upper limit }}{\text { Area at Under upper limit - Area at Under lower limit }}
$$

Dimana :

Density at Lower Limit

Density at Upper Limit

Area at Under Upper Limit

Area at Under Lower Limit
$=$ Densitas Batas Bawah

$=$ Densitas Batas Atas

$=$ Proporsi Kumulatif untuk pilihan jawaban yang dicari

$=$ Proporsi Kumulatif untuk pilihan jawaban yang sebelumnya
6). Merubah Nilai Skala (NS) terkecil menjadi sama dengan satu (1) dan mentransformasikan masing-masing skala menurut perubahan skala terkecil sehingga diperoleh nilai skala transformasi (Y).

Setelah dilakukan perubahan data dari skala ordinal ke skala interval, maka selanjutnya data tersebut diolah serta dianalisis sehingga data tersebut menghasilkan suatu kesimpulan.

\section{HASIL DAN PEMBAHASAN}

\section{Demografi responden}

Responden dipilih berdasarkan Teknik simple random sampling sehingga dari 116 orang, semua sampel berpeluang menjadi responden yang diwawancarai. Rincian demografi responden yang mencerminkan karakteristik dapat dilihat rinciannya dalam Tabel 1.

Tabel 2 menggambarkan tingkat Pendidikan responden yang mencapai level S1 hanya 3 orang atau $2,57 \%$ di Kampung Fafi, Katinim, Walal dan Maibo, tingkat Pendidikan tertinggi adalah SMA/Sederajat yakni mencapai 44 orang atau $37,93 \%$. Sedangkan level Pendidikan SMP/Sederajat mencapai 41 orang atau 35,34\%; dan tingkat Pendidikan SD mencapai 27 orang atau 23,28\%; yang paling sedikit adalah tingkat Pendidikan D3 hanya 1 orang atau $0,86 \%$.
Tabel 1 Jenis kelamin dan umur Responden

\begin{tabular}{lrr}
\hline Uraian & $\begin{array}{r}\text { Jumlah } \\
\text { Sampel }\end{array}$ & $\begin{array}{r}\text { Persentase } \\
(\%)\end{array}$ \\
\hline Pria & 44 & 37,93 \\
Wanita & 72 & 62,07 \\
Umur & & \\
(tahun) & & \\
$18-22$ & 9 & 7,76 \\
$23-27$ & 13 & 11,21 \\
$28-32$ & 15 & 12,93 \\
$33-37$ & 24 & 20,69 \\
$38-42$ & 31 & 26,72 \\
$43-47$ & 12 & 10,34 \\
$48-52$ & 6 & 5,17 \\
$53-57$ & 6 & 5,17 \\
\hline
\end{tabular}

Tabel 2 Tingkat Pendidikan responden

\begin{tabular}{|c|c|}
\hline \multicolumn{2}{|c|}{ Responden } \\
\hline \multicolumn{2}{|c|}{116} \\
\hline \multicolumn{2}{|c|}{ Skor } \\
\hline 5 & 3 \\
\hline 4 & 1 \\
\hline 3 & 44 \\
\hline 2 & 41 \\
\hline 1 & 27 \\
\hline
\end{tabular}

\section{Penerapan 8 Fungsi Keluarga}

Penerapan delapan fungsi keluarga dihimpun dalam Tabel 3. Data menunjukan bahwa penerapan 8 fungsi keluarga dengan kategori tinggi yang paling tinggi dilaksanakan oleh setiap keluarga adalah Fungsi Cinta Kasih yakni mencapai $88 \%$, yang terendah adalah fungsi reproduksi yakni $0 \%$. 
Tabel 3 Penerapan 8 Fungsi Keluarga

\begin{tabular}{lrrrrrr}
\hline \multirow{2}{*}{ Fungsi } & \multicolumn{7}{c}{ Tingkat penerapan } \\
\cline { 2 - 7 } & \multicolumn{2}{c}{ Tinggi } & \multicolumn{2}{c}{ Sedang } & \multicolumn{2}{c}{ Rendah } \\
\cline { 2 - 8 } & Jumlah & Persentase & Jumlah & Persentase & Jumlah & Persentase \\
\hline Agama & 75 & 65 & 41 & 35 & 0 & 0 \\
Sosbud & 1 & 1 & 111 & 96 & 4 & 3 \\
Cinta Kasih & 102 & 88 & 13 & 11 & 1 & 1 \\
Perlindungan & 60 & 52 & 55 & 47 & 1 & 1 \\
Reproduksi & 0 & 0 & 73 & 63 & 43 & 37 \\
Sosialisai dan & 3 & 3 & 56 & 48 & 57 & 49 \\
Pendidikan & & & & & & \\
Ekonomi & 28 & 24 & 88 & 76 & 0 & 0 \\
Lingkungan & 26 & 22 & 90 & 78 & 0 & 0 \\
\hline
\end{tabular}

\section{Kampung Katinim}

Penerapan 8 fungsi keluarga di Kampung Katinim disajikan dalam Table 4. Data pada tabel tersebut menunjukkan bahwa keluarga di kampung Katinim yang telah menerapkan indikator dari masing masing fungsi keluarga dengan Kategori tinggi yaitu meliputi aspek agama dan cinta kasih, sedangkan aspek sosbud, perlindungan, sosialisasi, ekonomi dan lingkungan sebagian besar berada pada kategori sedang. Secara keseluruhan tingkat penerapan 8 fungsi keluarga di Kampung Katimin adalah sebesar 73 persen berada pada kategori sedang. Dengan demikian dapat disimpulkan bahwa masyarakat di Kampung Katimin sudah relatif memahami aspek-aspek 8 fungsi keluarga.

\section{Kampung Walal}

Hasil penelitian terkait penerapan 8 fungsi keluarga di kampung Walal dapat dilihat pada Tabel 5. Data yang diperoleh menunjukkan bahwa keluarga di kampung Walal yang telah menerapkan indikator dari masing masing fungsi keluarga dengan Kategori tinggi yaitu meliputi aspek agama, cinta kasih dan perlindungan. sedangkan aspek sosbud, reproduksi, sosialisasi, ekonomi dan lingkungan, sebagian besar berada pada kategori sedang. Secara keseluruhan tingkat penerapan 8 fungsi keluarga di Kampung Walal adalah sebesar 64 persen berada pada kategori sedang. Sama halnya dengan kampung Katimin, kecenderungn masyarakat Kampung Walal sudah relatif memahami dan menerapkan aspekaspek 8 fungsi keluarga.

\section{Kampung Waibo}

Hasil penelitian pada Kampung Waibo dapat dilihat pada Tabel 6 yang menunjukkan bahwa keluarga di kampung Maibo yang telah menerapkan indikator dari masing - masing fungsi keluarga dengan Kategori tinggi yaitu meliputi aspek agama, cinta kasih , perlindungan dan lingkungan. Sedangkan aspek sosbud, reproduksi, ekonomi sebagian besar berada pada kategori sedang. Secara keseluruhan tingkat penerapan 8 fungsi keluarga di Kampung Maibo adalah sebesar 45 persen berada pada kategori sedang. Pada Kampung Maibo penerapan aspek sosialisasi dan pendidikan sebagian besar berada pada kategori rendah yaitu 57 persen. Hasil wawancara terungkap bahwa di kampung ini masih seringkali dijumpai kasus-kasus pertengkaran antara orang tua di depan anak. Hal ini juga menunjukkan dan berkolerasi dengan rendahnya aspek sosialisasi dan pendidikan dalam keluarga. 
Tabel 4 Penerapan 8 fungsi keluarga di Kampung Katinim

\begin{tabular}{|c|c|c|c|c|c|c|}
\hline \multirow{3}{*}{ Fungsi } & \multicolumn{6}{|c|}{ Tingkat penerapan } \\
\hline & \multicolumn{2}{|c|}{ Tinggi } & \multicolumn{2}{|c|}{ Sedang } & \multicolumn{2}{|c|}{ Rendah } \\
\hline & Jumlah & $\%$ & Jumlah & $\%$ & Jumlah & $\%$ \\
\hline Agama & 18 & 60 & 12 & 40 & 0 & 0 \\
\hline Sosbud & 0 & 0 & 29 & 96.667 & 1 & 3.33333 \\
\hline Cinta Kasih & 24 & 80 & 6 & 20 & 0 & 0 \\
\hline Perlindungan & 0 & 0 & 29 & 96.667 & 1 & 3.33333 \\
\hline Reproduksi & 0 & 0 & 21 & 70 & 9 & 30 \\
\hline $\begin{array}{l}\text { Sosialisai dan } \\
\text { Pendidikan }\end{array}$ & 0 & 0 & 19 & 63.333 & 11 & 36.6667 \\
\hline Ekonomi & 0 & 0 & 30 & 100 & 0 & 0 \\
\hline Lingkungan & 0 & 0 & 30 & 100 & 0 & 0 \\
\hline Total & 5.25 & 17.5 & 22 & 73.333 & 2.75 & 9.16667 \\
\hline
\end{tabular}

Tabel 5 Penerapan 8 fungsi keluarga di Kampung Walal

\begin{tabular}{lcccccc}
\hline & \multicolumn{7}{c}{ Tingkat penerapan } \\
\cline { 2 - 7 } Fungsi & \multicolumn{2}{c}{ Tinggi } & \multicolumn{2}{c}{ Sedang } & \multicolumn{2}{c}{ Rendah } \\
\cline { 2 - 7 } & Jumlah & $\%$ & Jumlah & $\%$ & Jumlah & $\%$ \\
\hline Agama & 26 & 86.666 & 4 & 13.333 & 0 & 0 \\
Sosbud & 0 & 0 & 30 & 100 & 0 & 0 \\
Cinta Kasih & 28 & 93.33 & 1 & 3.333 & 1 & 3.333 \\
Perlindungan & 17 & 56.66 & 13 & 43.33 & 0 & 0 \\
Reproduksi & 0 & 0 & 26 & 86.66 & 4 & 13.33 \\
Sosialisai dan & 0 & 0 & 20 & 66.66 & 10 & 33.33 \\
Pendidikan & & & & & & 0 \\
Ekonomi & 0 & 0 & 30 & 100 & 0 & 0 \\
Lingkungan & 0 & 0 & 30 & 100 & 1.875 & 6.25 \\
\hline Total & 8.875 & 29.583 & 19.25 & 64.1666 & & 0 \\
\hline
\end{tabular}

Tabel 6 Penerapan 8 fungsi keluarga di Kampung Maibo

\begin{tabular}{lcccccc}
\hline \multirow{2}{*}{ Fungsi } & \multicolumn{6}{c}{ Tingkat penerapan } \\
\cline { 2 - 7 } & \multicolumn{2}{c}{ Tinggi } & \multicolumn{2}{c}{ Sedang } & \multicolumn{2}{c}{ Rendah } \\
\cline { 2 - 7 } & Jumlah & $\%$ & Jumlah & $\%$ & Jumlah & $\%$ \\
\hline Agama & 15 & 50 & 14 & 46.66 & 0 & 0 \\
Sosbud & 1 & 3.333 & 27 & 90 & 1 & 3.3333 \\
Cinta Kasih & 24 & 80 & 5 & 16.666 & 0 & 0 \\
Perlindungan & 21 & 70 & 8 & 26.66 & 0 & 0 \\
Reproduksi & 0 & 0 & 13 & 43.333 & 16 & 53.33 \\
Sosialisai dan & 2 & 6.666 & 10 & 33.33 & 17 & 56.666 \\
Pendidikan & & & & & & \\
Ekonomi & 11 & 36.66 & 18 & 60 & 0 & 0 \\
Lingkungan & 12 & 40 & 11.875 & 39.583 & 4.25 & 14.166 \\
Total & 10.75 & 35.833 & 13.35 & 44.53 & 4.781 & 15.935 \\
\hline
\end{tabular}


Analisis Faktor-Faktor yang Mempengaruhi Tingkat Penerapan Delapan Fungsi keluarga

Berdasarkan pengolahan data primer, maka untuk mengetahui pengaruh Pendidikan formal (X1), umur
(X2), Frekuensi Ikut sosialisasi (X3), terhadap tingkat Tingkat penerapan Delapan Fungsi Keluarga (Y) maka diperoleh koefisien regresi linier berganda antara variabel bebas dengan variabel terikat disajikan pada Tabel 7 .

Tabel 7 Koefisien Regresi Linier Berganda Antara Variabel Bebas Dengan Variabel Terikat

\begin{tabular}{lcl}
\hline \multicolumn{1}{c}{ Variabel } & Koefisien Regresi & \multicolumn{1}{c}{ t hitung } \\
\hline Pendidikan Formal $\left(\mathrm{X}_{1}\right)$ & 0.070 & $2.034^{*}$ \\
Umur $\left(\mathrm{X}_{2}\right)$ & -0.007 & 0.070 \\
Frekwensi Sosialisasi $\left(\mathrm{X}_{3}\right)$ & 0.564 & $8.434^{* *}$ \\
\hline Constant $=1.837$ & & \\
Koef. Determinasi $\left(\mathrm{R}^{2}\right)=0.430$ & & \\
Koef. Korelasi $(\mathrm{R})=0.656$ & & \\
$\mathrm{t}$ tabel $(0,05)=1.658$ & & \\
$\mathrm{t}$ tabel $(0,01)=2.617$ & & \\
\hline Keterangan & &
\end{tabular}

Keterangan :

* = signifikan pada tingkat kepercayaan $95 \%$

** = Sangat signifikan pada tingkat kepercayaan $99 \%$

Hasil analisis regresi linear berganda untuk tingkat Pendidikan, Umur dan Frekuensi mengikuti sosialisasi diperoleh model persamaan sebagai berikut :

Dimana :

$$
\mathbf{Y}=1.837+\mathbf{0 . 0 7 0} \mathbf{X}_{1}-0.007 \mathbf{X}_{\mathbf{2}}+0.564 \mathbf{X}_{\mathbf{3}}
$$

$$
\begin{array}{ll}
\mathrm{Y} & =\text { Tingkat Penerapan } 8 \text { Fungsi Keluarga } \\
\mathrm{a} & =\text { Konstanta } \\
\beta_{1}-\beta 3 & =\text { Koefisien Regresi } \\
\mathrm{X}_{1} & =\text { Pendidikam } \\
\mathrm{X}_{2} & =\text { Umur } \\
\mathrm{X}_{3} & =\text { Frekwensi ikut sosialisasi } \\
\mathrm{e} & =\text { Faktor Galat }
\end{array}
$$

Hasil perhitungan analisis korelasi diketahui bahwa korelasi antara variabel $\mathrm{X}_{1}$ sampai dengan $\mathrm{X}_{3}$ dengan variabel $\mathrm{Y}$ adalah sebesar 0.415. Hal ini menjelaskan bahwa tingkat tingkat penerapan 8 fungsi keluarga di Kabupaten Sorong dipengaruhi oleh ketiga karakteristik responden sebesar $41.50 \%$, dan sisanya sebesar $58.50 \%$ dipengaruhi oleh faktor lainnya di luar model. Menurut Sarwono (2006) koefisien korelasi sebesar 0.415 menunjukkan bahwa korelasi variabel
$\mathrm{X} 1$ - X3 secara bersamaan dengan variabel Y termasuk dalam korelasi kuat. Hasil analisis regresi memperlihatkan bahwa hubungan positif antara tingkat pendidikan terhadap tingkat penerapan 8 fungsi keluarga (Y), demikian juga halnya pada variabel ferkuensi ikut sosialisasi berhubungan positif terhadap penerapan delapan fungsi keluarga. Adapun variabel umur berhubungan negatif demgan tingkat penerapan 8 fungsi keluarga. 


\section{Pengaruh Secara Simultan}

Untuk menguji tingkat keberartian pengaruh variabel bebas secara bersama-sama (simultan) terhadap tingkat penerapan 8 fungsi keluarga, dapat dilihat pada analisis varians atau uji statistik F. Analisis varians uji $\mathrm{F}$ disajikan pada Tabel 8 . Berdasarkan hasil analisis varians uji statistik F, diketahui F hitung (28.166) lebih besar daripada $\mathrm{F}$ tabel $(0.05: 3.112$ )$=2.68$. Semua variabel bebas, yang terdiri dari pendidikan formal (X1), umur (X2), frekuensi sosialisasi (X3) secara bersama-sama berpengaruh terhadap tingkat penerapan 8 fungsi keluarga. Hal ini mengandung pengertian bahwa apabila variabel bebas tersebut ditambah atau dikurangi dapat meningkatkan atau menurunkan tingkat penerapan 8 fungsi keluarga.

\section{Pengaruh Secara Parsial}

Secara parsial pengaruh masingmasing variabel ditunjukkan oleh uji t, seperti pada Tabel 9. Berdasarkan Tabel 4.15 hasil uji t memberikan gambaran bahwa variabel tingkat pendidikan formal berpengaruh nyata terhadap penerapan 8 fungsi keluarga. Variabel frekuensi mengikuti sosialisasi berpengaruh sangat nyata terhadap prnrrapan 8 fungsi keluarga. Sedangkan variabel umur tidak berpengaruh nyata terhadap penerapan 8 fungsi keluarga. Tingkat pendidikan formal membentuk nilai bagi seseorang terutama dalam menerima hal baru (Suhardjo, 2007).

\section{Pengaruh Pendidikan Formal terhadap Tingkat Penerapan 8 Fungsi Keluarga}

Berdasarkan hasil pengujian statistik, nilai t hitung (2.034) lebih besar daripada $t$ tabel $(0.05 ; 3.112)=1.658$. Hal ini berarti bahwa pendidikan formal berpengaruh nyata terhadap tingkat tingkat penerapan delapan fungsi keluarga. Dengan tingkat pendidikan yang dimiliki seseorang akan berdampak pada pola pikir dan wawasan sehingga akan mengarahkan seseorang dalam mengambil keputusan (Cahyaningtyas, 2016). Artinya semakin tinggi tingkat pendidikan seseorang maka cenderung semakin tepat dan benar dalam mengambil keputusan, termasuk didalamnya yang terkait dengan penerapan delapan fungsi keluarga yang dianggap baik (Suhardjo, 2007). Seseorang akan lebih memyadari tentang manfaat delapan fungsi keluarga dalam kehidupan sehari-hari, sehingga cenderung untuk menerapkan.

Tabel 8 Analisis Varians Uji F

\begin{tabular}{llcclc}
\hline & Sumber variasi & Jumlah Kuadrat & Derajat Bebas & Kuadrat rata-rata & F \\
\hline \multirow{2}{*}{1} & Regresi & 103.872 & 3 & 34.624 & 28.166 \\
& Residual & 137.680 & 112 & 1.229 & \\
& Total & 241.552 & 115 & & \\
\hline
\end{tabular}

Sumber : Hasil Olahan SPSS 21.0

Tabel 9 Hubungan Parsial Variabel Bebas Terhadap Variabel Terikat

\begin{tabular}{cccccc}
\hline \multirow{2}{*}{ Variabel } & \multirow{2}{*}{ t hitung } & \multicolumn{2}{c}{ t table } & \multirow{2}{*}{ Peluang } & \multirow{2}{*}{ Keterangan } \\
& & $\boldsymbol{\alpha} \mathbf{0 , 0 5}$ & $\boldsymbol{\alpha ~ 0 , 0 1}$ & & Signifikan \\
$\mathrm{X}_{1}$ & 2.034 & 1.658 & 2.617 & .044 & Tidak Signifikan \\
$\mathrm{X}_{2}$ & -.070 & 1.658 & 2.617 & .944 & Sangat Signifikan \\
$\mathrm{X}_{3}$ & 8.434 & 1.658 & 2.617 & .000 & \\
\hline
\end{tabular}




\section{Pengaruh Umur terhadap Tingkat Penerapan 8 Fungsi Keluarga}

Berdasarkan hasil pengujian statistik nilai t hitung (0.70) lebih kecil daripada $t$ tabel $((0.05 ; 3.112)=1.658$. Hal ini berarti bahwa variabel umur tidak berpengaruh nyata terhadap tingkat penerapan delapan fungsi keluarga.. Dengan perkataan lain bahwa seseorang lebih tua atau sebaliknya lebih berusia muda tidak menentukan tinggirendahnya penerapan delapan fungsi keluarga. Perilaku dalam menerapkan 8 fungsi keluarga, lebih dipengaruhi oleh pemahaman, kesadaran dan kemauan seseorang.

\section{Pengaruh Frekuensi Sosialisasi terhadap Tingkat Penerapan 8 Fungsi Keluarga}

Berdasarkan hasil pengujian statistik nilai t hitung (8.434) lebih besar daripada t tabel $(0.01 ; 3.112)=2.617$. Hal ini berarti bahwa variabel frekuensi sosialisasi berpengaruh sangat nyata terhadap tingkat penerapan 8 fungsi keluarga. Hal ini berarti bahwa penyuluhan dan bentuk edukasi dalam program 8 fungsi keluarga yang diikuti oleh seseorang berpengaruh sangat nyata terhadap tingkat penerapan 8 fungsi keluarga. Semakin sering seseorang mengikuti penyuluhan/sosialisasi, maka semakin paham sehingga semakin terdorong untuk menerapkannya. Ary $\mathrm{H}$. Gunawan menyatakan bahwa semua usaha sadar yang dilakukan untuk membantu perkembangan kepribadian serta kemampuan anak dan orang dewasa diluar sistem persekolahan melalui pengaruh yang sengaja dilakukan melalui beberapa sistem dan metode penyampaian seperti; kursus, bahan bacaan, radio, televisi, penyuluhan dan media komunikasi lainnya adalah Pendidikan non Formal.

\section{Pengaruh Tingkat Penerapan 8 Fungsi keluarga terhadap Kesejahteraan Keluarga}

Berdasarkan hasil uji statistik, nilai $t$ hitung (2.220) lebih besar daripada $t$ tabel $(0.05 ; 3,112)=1.658$. Dengan demikian, kesimpulan statistik yang diperoleh adalah tingkat penerapan 8 Fungsi keluarga berpengaruh nyata terhadap tingkat kesejahteraan keluarga.

\section{KESIMPULAN}

Tingkat Penerapan delapan fungsi keluarga pada 4 (empat) kampung secara umum sebagian besar berada pada kategori sedang. Hasil analisis regresi linier berganda, menunjukkan bahwa variabel Pendidikan Formal (X1), Umur (X2), Frekuensi Sosialisasi (X3) secara bersama-sama berpengaruh terhadap Tingkat Penerapan delapan Fungsi keluarga (Y). Hasil pengujian hubungan parsial menunjukkan variabel pendidikan formal (X1) berpengaruh nyata, umur (X2) tidak berpengaruh nyata terhadap Tingkat penerapan delapan fungsi keluarga, sedangkan variabel Frekuensi sosialisasi (X3) berpengaruh sangat nyata terhadap Tingkat penerapan delapan fungsi keluarga. Hasil analisis regresi linier sederhana, menunjukkan bahwa variabel Tingkat penerapan delapan fungsi keluarga (Y) berpengaruh nyata terhadap Tingkat kesejahteraan keluarga (Z1). Hasil analisis regresi linier sederhana, menunjukkan bahwa variabel Tingkat penerapan delapan fungsi keluarga (Y) tidak berpengaruh nyata terhadap Lingkungan sehat (Z2). 
DAFTAR PUSTAKA

Annur M.A. (2013). Difusi dan Adopsi Inovasi Penanggulangan Kemiskinan (Studi Difusi dan Adopsi Inovasi dalam Layanan "Mbela Wong Cilik" Unit Pelayanan Terpadu Penanggulangan Kemiskinan (UPTPK) di Kabupaten Sragen). Akademi Berbagi Surakarta. Journal of Rural and Development, IV(1)

Handayani, A., Yulianti, P.D., Ardini, S.N. (2018). Membina Keluarga Sejahtera Melalui Penerapan 8 Fungsi Keluarga. JABDIPAMAS: Jurnal Pengabdian Kepada Masyarakat, II(1):76-80, Doi: http://dx.doi.org/10.30734/jabdipamas.v2i1.162

BKKBN. (2019a). Pusat penelitian KB KS. Survei Kinerja dan Akuntabilitas Program Kependudukan, keluarga berencana dan pembangunan keluarga tahun 2018. Jakarta

BKKBN. (2019b). Profil Keluarga Indonesia.

http://www.feb.unpad.ac.id/doku men/files/BUKUKEPENDUDUKAN.pdf.

BAPENNAS. (2017). Pedoman Penyusunan Rencana Aksi Tujuan Pembangunan Berkelanjutan (Tpb)/ Sustainable Development Goals (Sdgs)

Cahyaningtyas, A., Tenrisana, A.A., Dewi Triana, D., Prastiwi, D.A., Nurcahyo, E.H., Jamilah, Aminiah, N., Tiwa, V.D. (2016). Pembangunan ketahanan keluarga. Kemen PPPA BPS https://www.kemenpppa.go.id/lib/ uploads/list/9455b-bukupembangunan-ketahanan-keluarga 2016.pdf.
Elmanora, H.D., Muflikhati, I. (2015). Kesejahteraan keluarga dan kualitas lingkungan pengasuhan pada anak usia prasekolah. Jur. Ilm. Kel. \& Kons., 8(2): 96-105.

Sugiyono, (2011). Metode Penelitian Kuantitatif, Kualitatif dan R\&D. Bandung: Penerbit Alfabeta.

Suhardjo. (2007). Definisi Tingkat Pendidikan.

https://dinikomalasari.wordpress.c om/2014/04/07/defenisi-tingkatpendidikan/. download 16 Februari 2021

Republik Indonesia. (2009). Undang undang RI Nomor 52 Tahun 2009 tentang Perkembangan Kependudukan dan Pembangunan Keluarga. https://jdih.kemenpppa. go.id, (diakses: 8 Januari 2021)

Wijayanti, U., \& Berdame, D. (2019). Implementasi Delapan Fungsi Keluarga di Provinsi Jawa Tengah. Jurnal Komunikasi, 11(1), 15-29. doi:http://dx.doi.org/10.24912/jk. $\underline{v 11 i 1.2475}$ 